\title{
High-throughput tuning of ovarian cancer spheroids for on-chip invasion assays
}

\author{
Changchong Chen, ${ }^{\mathrm{a}}$ Yong He, ${ }^{\mathrm{a}}$ Elliot Lopez, ${ }^{\mathrm{a}}$ Franck Carreiras, ${ }^{\mathrm{b}}$ Ayako Yamada, ${ }^{\mathrm{a}}$ Marie-Claire \\ Schanne-Klein, ${ }^{\mathrm{c}}$ Ambroise Lambert, ${ }^{\mathrm{b}}$ Yong Chen, ${ }^{\mathrm{a} *}$ Carole Aiméa* \\ a PASTEUR, Département de chimie, École normale supérieure, PSL University, Sorbonne \\ Université, CNRS, 75005 Paris, France \\ ${ }^{b}$ Equipe de Recherche sur les Relations Matrice Extracellulaire-Cellules, ERRMECe, (EA1391), \\ Groupe Matrice Extracellulaire et physiopathologie (MECuP), Institut des Materiaux, I-MAT \\ (FD4122), CY Cergy Paris Université, France \\ ${ }^{c}$ Laboratoire d'Optique et Biosciences, École polytechnique, CNRS, Inserm, Institut \\ Polytechnique de Paris, F-91128 Palaiseau, France \\ e-mail: yong.chen@ens.psl.eu / carole.aime@ens.psl.eu
}

\begin{abstract}
:
We developed an invasion assay by using microfabricated culture devices. First, ovarian tumor spheroids were generated with a culture patch device consisting of an agarose membrane formed with a honeycomb microframe - the patch - and gelatin nanofiber backbone. By changing the dimensions of the honeycomb compartments we were able to control the number of cells and size of the spheroids. When the spheroids were placed on a patch coated with a thin membrane of fibrillary type I collagen, spheroid disruption was observed due to substrate induced cell migration. This process is straightforward and should be applicable to other cancer types, as well as assays under microfluidic conditions, thereby holding the potential for use in tumor modeling and anticancer drug development.
\end{abstract}

Keywords: Tumor spheroid, Epithelial-to-mesenchymal transition, Culture substrate, Microfluidics 
bioRxiv preprint doi: https://doi.org/10.1101/2021.11.24.469887; this version posted November 25, 2021. The copyright holder for this preprint (which was not certified by peer review) is the author/funder, who has granted bioRxiv a license to display the preprint in perpetuity. It is made

\section{Introduction} available under aCC-BY-NC-ND 4.0 International license.

Progress in cancer research relies partially on our ability to provide relevant in vitro models, which recapitulate important features of tumor growth, metastasis, and angiogenesis [1]. In vitro generation of tumor spheroids, for example, is a simple yet reliable approach for predicting tumor growth dynamics and microenvironmental dependencies [2,3]. Spheroids are formed by self-assembly of cells through different types of intercellular interactions, including cadherin- and integrin-mediated interactions, as well as involving the vitronectin/ $\alpha$ v integrin adhesive system [4]. Ovarian cancer (OC) cells are likely to form spheroids, which seem to be the preferential mode of survival of floating OC cells, as well as the starting point for metastatic activity. The formation of such aggregates may contribute to protect them from the circulating microenvironment. Indeed, cells within spheroids have been shown to resist anoikis [5] and to be more prone to resist chemotherapies [6,7]. As such, building up 3D cellular organizations has become a key target in providing biologically relevant in vitro systems for cancer research [8]. In this context, many research efforts have been dedicated to the engineering of spheroid models using various strategies such as hanging drop method [9,10], rotating walls culture [11], hydrogels [12-17], or non-adherent substrates including bovine serum albumin (BSA) [18,19], polyHEMA [20,21], agarose [5,22,23] or Pluronic F [24,25].

Beside the difficulties for obtaining stable spheroids with controlled homogeneity, two key challenges can be emphasized for the development of in vitro cancer models. The first one is the ability to tune the number of cells, and the size of the spheroids so as to reproduce metastasis evolution during different stages of ovarian cancer, as well as different types of cancer. A second important challenge is to recapitulate the multidimensional and constantly evolving tumor microenvironment, which also includes the structural matrix, shear stress and soluble - circulating - factors. To address all of these, we first used micro-structured supports - called patches - with repellant coating for the fabrication of size-controlled spheroids with high efficiency (Figure 1A,B). Here, we show that by playing with the dimensions of the patch, we can vary the number of cells in and the size of the spheroids, and reproducibly obtain stable OC spheroids that can easily be handled for further use. Next, spheroids were placed on a second type of patch coated with a thin membrane of type I collagen mimicking the extracellular matrix (ECM-patch) to observe substrate dependent spheroid disruption (Figure 1C,D). This approach should be spheroid-type independent and applicable to assays under different experimental conditions. Of note, the self-standing area of the ECM membrane device has a low stiffness $(<20 \mathrm{kPa})$ and a large permeability, which play important roles and is unique compared to both conventional culture substrates and plastic porous membranes. As an illustration, this device effectively allows to monitor the invasive behavior of SKOV-3 human OC cells providing a unique insight into cells transitioning within the epithelial to mesenchymal transition spectrum.

\section{Materials and methods}


bioRxiv preprint doi: https://doi.org/10.1101/2021.11.24.469887; this version posted November 25, 2021. The copyright holder for this preprint (which was not certified by peer review) is the author/funder, who has granted bioRxiv a license to display the preprint in perpetuity. It is made 2.1 Fabrication of the patches available under aCC-BY-NC-ND 4.0 International license.

The patches were fabricated by photolithography and soft-lithography. SU-8 molds were fabricated by photolithography. For the $50 \mu \mathrm{m}$-high patch, SU-8 3050 was spin coated on a silicon wafer at 3000 rpm for $30 \mathrm{~s}$. For the $200 \mu \mathrm{m}$-high patch, SU-8 3050 was spin coated on a silicon wafer at $2000 \mathrm{rpm}$ for $30 \mathrm{~s}$ twice, followed each time by a soft bake. Then, a honeycomb frame of 200 or $400 \mu \mathrm{m}$ in width was directly patterned by UV exposure at $250 \mathrm{~mJ} / \mathrm{cm}^{2}$. This SU-8 mold was then exposed in trimethylchlorosilane (TMCS, Sigma, France) vapor for $10 \mathrm{~min}$ for surface treatment. Afterward, a mixture of PDMS (GE RTV 615) pre-polymer and its cross-linker at a weight ratio of 10:1 was casted on the SU-8 mold. After curing at $75^{\circ} \mathrm{C}$ for 4 hours, the PDMS layer was peeled off. Then, this replicated PDMS structure was placed on a glass plate and a solution of a photo-crosslinking polymer $\left(\right.$ Ormostamp ${ }^{\circledR}$ ) was injected in the free space of the PDMS-glass assembly, followed by UV exposure at $1500 \mathrm{~mJ} / \mathrm{cm}^{2}$, and removal of the PDMS mold. The patches were then coated with gold by sputter deposition for electrospinning (for the fabrication of the spheroid-patches, Figure 1A,B) or for improving hydrophilicity and drop casting of type I collagen (for the fabrication of the ECM patch, Figure 1C,D).

\subsection{Electrospinning of gelatin}

Electrospinning is the extrusion of a soluble biopolymer assisted with electrical field. It is interesting for cell biologists because it provides a net-like structure made of cross-linked nanofibers mimicking the ECM [26]. The gelatin solution was prepared by dissolving $100 \mathrm{mg}$ of gelatin in a mixture of 420 $\mu \mathrm{L}$ acetic acid, $280 \mu \mathrm{L}$ ethyl acetate and $200 \mu \mathrm{L}$ DI water. Citric acid (10 mg) was then added as thermal cross-linking agent before electrospinning. The mixture was stirred for 4 hours at room temperature. Gelatin was electrospun onto a gold-coated patch fixed on a tin foil $(7 \mathrm{~cm}$ in diameter) at a voltage of $11 \mathrm{kV}$ for 7 minutes at a flow rate of $0.2 \mathrm{~mL} / \mathrm{h}$, with a controlled humidity of $35 \%$ at room temperature $\left(20 \sim 25^{\circ} \mathrm{C}\right)$. The distance between the metal needle and the patch was 9-12 cm. After electrospinning, the patch was detached from the tin foil and transferred into an oven working at $140^{\circ} \mathrm{C}$ for 4 hours for high temperature cross-linking of gelatin.

\subsection{Agarose drop casting}

To promote the formation of spheroids, the gelatin nanofiber layer was coated with a solution of agarose (Fisher Scientific, France). $20 \mu \mathrm{L}$ of $0.2 \mathrm{w} / \mathrm{v} \%$ solution in DI water was poured on the patch and let dry in air at room temperature. Note that the gelatin fiber layer was necessary to maintain the agarose film on the porous patch, while preserving the porosity of the support.

\subsection{ECM patch}


bioRxiv preprint doi: https://doi.org/10.1101/2021.11.24.469887; this version posted November 25, 2021. The copyright holder for this preprint (which was not certified by peer review) is the author/funder, who has granted bioRxiv a license to display the preprint in perpetuity. It is made

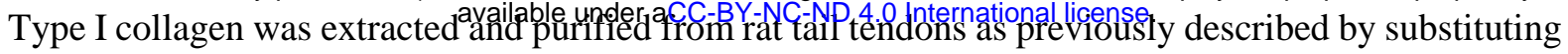
$500 \mathrm{mM}$ acetic acid with $3 \mathrm{mM}$ hydrochloric acid [27,28]. Collagen purity was assessed by electrophoresis and its concentration estimated by hydroxyproline titration [29]. Type I collagen (0.5 $\mathrm{mg} / \mathrm{mL}$ in PBS, $\mathrm{pH}=9.0$ ) was drop cast by pouring $20 \mu \mathrm{L}$ of the solution on a patch with dimensions: $50 \mu \mathrm{m}$ thickness and $400 \mu \mathrm{m}$ width of honeycombs and let dry in air at room temperature.

\subsection{Second harmonic generation / 2-photon excited fluorescence}

We used a custom-built laser-scanning multiphoton microscope and recorded Second Harmonic Generation (SHG) images as previously described [30]. Excitation was provided by a femtosecond titanium-sapphire laser (Mai-Tai, Spectra-Physics) tuned to $860 \mathrm{~nm}$, scanned in the XY directions using galvanometric mirrors and focused using a 25× objective lens (XLPLN25XWMP2, Olympus), with a resolution of $0.35 \mu \mathrm{m}$ (lateral) $\times 1.2 \mu \mathrm{m}$ (axial) and a Z-step of $0.5 \mu \mathrm{m}$ for the acquisition of Z-stack images. We used circular polarization in order to image all structures independently of their orientation in the image plane, using $100 \mathrm{kHz}$ acquisition rate and $420 \times 420 \mathrm{~nm}^{2}$ pixel size.

\subsection{SEM imaging}

Samples were coated with gold for $60 \mathrm{~s}$ with a sputtering current of $50 \mathrm{~mA}$ before imaging. Samples were fixed on conductive-tapes for imaging with a TM3030 Tabletop Microscope (Hitachi HighTechnologies Corporation, Japan) equipped with TM3030 software and working at an acceleration voltage of $15 \mathrm{kV}$.

\subsection{Cell culture}

SKOV-3 cells (ATCC1, HTB77 ${ }^{\mathrm{TM}}$ ), human ovarian adenocarcinoma cell line, were purchased from ATCC (American Type Culture Collection, Manassas, VA). SKOV-3 cells were cultured in RPMI1640 glutaMAX containing $0.07 \%$ sodium bicarbonate supplemented with $10 \%$ fetal calf serum and $100 \mathrm{U} / \mathrm{mL}$ penicillin streptomycin (all reagents were purchased from Thermo Fisher Scientific). Cells were cultured in T25 cell culture flasks in a humidified air atmosphere with $5 \% \mathrm{CO}_{2}$ at $37{ }^{\circ} \mathrm{C}$.

\subsection{Invasion assay}

ECM patches were immersed in 70\% ethanol for $5 \mathrm{~min}$ for sterilization, and washed 3 times for $5 \mathrm{~min}$ in sterile PBS. SKOV-3 spheroids, 3 days old, were recovered and seeded on ECM-patch. Patches were then transferred to a controlled atmosphere $\left(37^{\circ} \mathrm{C}, 5 \% \mathrm{CO}_{2}\right)$ before immunostaining of the cells.

\subsection{Immunofluorescence staining}

Cells were fixed in 4\% paraformaldehyde (PFA) in PBS for 10 minutes, rinsed three times with PBS. The cells were permeabilized for 4 minutes with $0.1 \%$ Triton x100 in PBS at $4{ }^{\circ} \mathrm{C}$, washed again and 
bioRxiv preprint doi: https://doi.org/10.1101/2021.11.24.469887; this version posted November 25, 2021. The copyright holder for this preprint (which was not certified by peer review) is the author/funder, who has granted bioRxiv a license to display the preprint in perpetuity. It is made

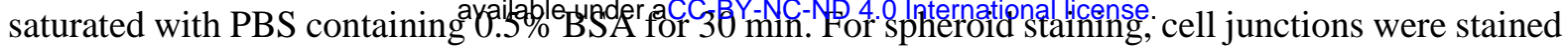
overnight at $4{ }^{\circ} \mathrm{C}$ with a primary E-cadherin (610181, BD Biosciences) staining and secondary IgG, IgM (H+L) Goat anti-Mouse, Alexa Fluor ${ }^{\mathrm{TM}} 488$, Invitrogen ${ }^{\mathrm{TM}}$ for 1 hour at room temperature. Cells were washed 3 times with PBS for 5 min each time to remove unbound antibody. For additional staining, we used EPCAM CD326 monoclonal antibody conjugated with Alexa Fluor ${ }^{\circledR ~} 488$ (eBioscience ${ }^{\mathrm{TM}}$ ). Tumor cells were incubated overnight at $4{ }^{\circ} \mathrm{C}$ at a $1 / 20$ dilution and washed 3 times with PBS for 5 min each time to remove unbound antibody.

For the invasion assay, cells were incubated overnight at $4{ }^{\circ} \mathrm{C}$ with recombinant anti-vimentin antibody conjugated with Alexa Fluor ${ }^{\circledR} 568$ (ab202504, Abcam®) at a 1/1000 dilution. After washing the actin cytoskeleton was stained with Alexa Fluor ${ }^{\circledR} 488$ Phalloidin in PBS (containing 1\% DMSO from the original stock solution, Abcam ${ }^{\circledR}$ ) for $40 \mathrm{~min}$ at room temperature in a dark chamber. Cell nuclei were then stained with DAPI (4,6-diamidino-2-phenylindole dihydrochloride, Molecular Probe $\left.{ }^{\circledR}\right)$ for 15 $\min$.

Immunofluorescent labelling was observed with a confocal microscope (LSM710, Zeiss) equipped with 405, 488, and $543 \mathrm{~nm}$ lasers and with LSM ZEN 2009 software and using $1 \mu \mathrm{m}$ z-stack intervals and sequential scanning. Images were processed with ImageJ.

\section{Results and discussion}

\subsection{Patch device and coating}

Figure 1A-B describe our strategy for spheroid growth and control of the number of cells and spheroid size. We use microfabricated patches that are circular culture supports, $1.3 \mathrm{~cm}$ in diameter, with a honeycomb microporous pattern. These patches were fabricated by photolithography and softlithography for obtaining a PDMS replica. Then the patch can be obtained by injecting a photocrosslinking polymer to the replica on a glass, and UV-assisted curing. The porosity of the microframe presents many advantages notably for limiting the contribution of the mechanical properties of a solid substrate, while preserving the biological permeability for exchanges of circulating soluble factors. These supports have been shown to allow the maintenance and differentiation of human induced pluripotent stem cells (hiPSCs) over days [31-37]. Patches were coated with gold prior to electrospinning of gelatin (Figure 1A). On top of the electrospun gelatin layer, agarose is drop cast ensuring a non-adherent coating. After this step, human ovarian carcinoma - SKOV-3 - cells were seeded and allowed to form spheroids within the honeycomb chambers (Figure 1B). 


\section{SPHEROID GROWTH} available under aCC-BY-NC-ND 4.0 International license.

A Fabrication of the patch for spheroid growth - Top view of a patch

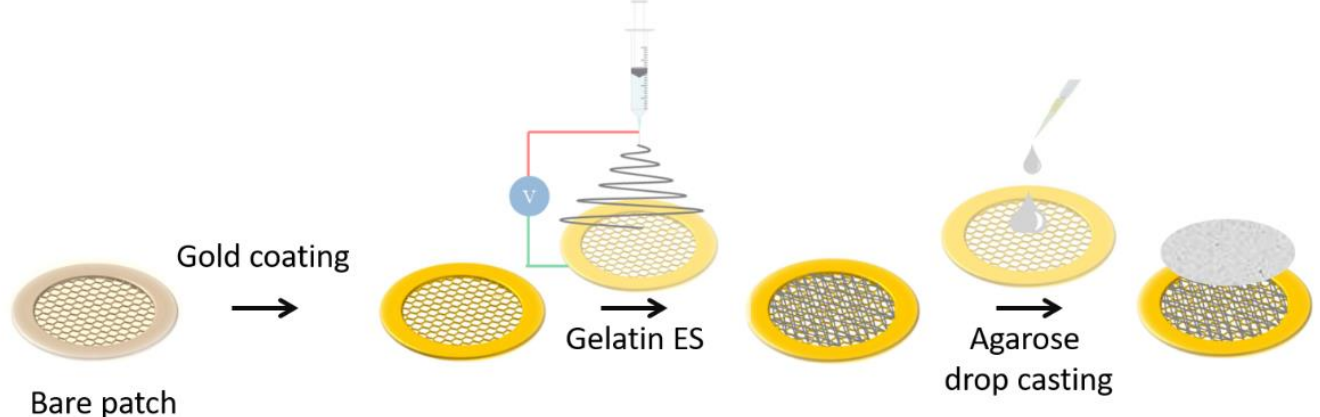

B Spheroid growth - Side view of a patch

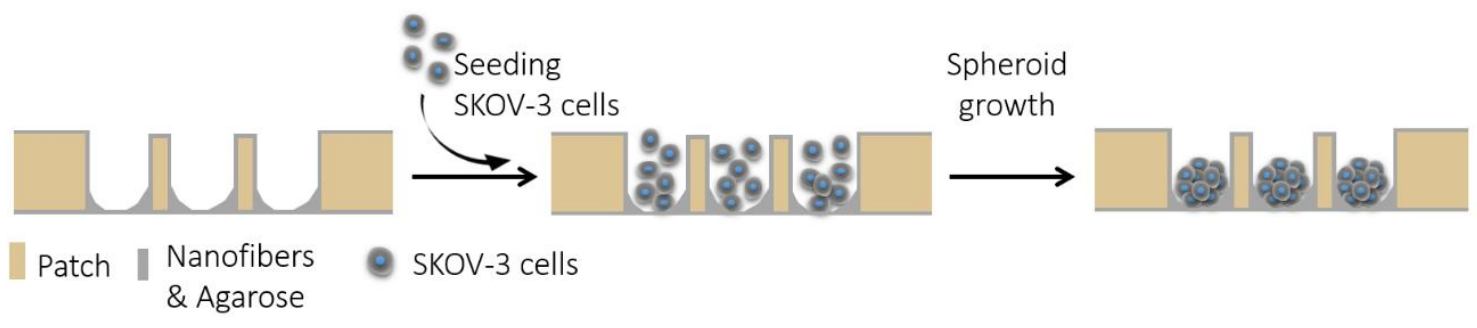

\section{SPHEROID SEEDING ON ECM PATCH}

C Fabrication of the ECM patch - Top view of a patch

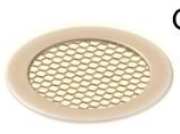

Bare patch
Gold coating

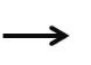

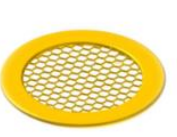

Collagen I

drop casting

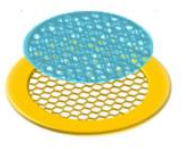

D Spheroid transfer and re-seeding on ECM patch - Side view of a patch

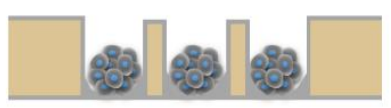

Patch for spheroid growth

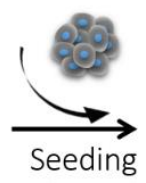

spheroids

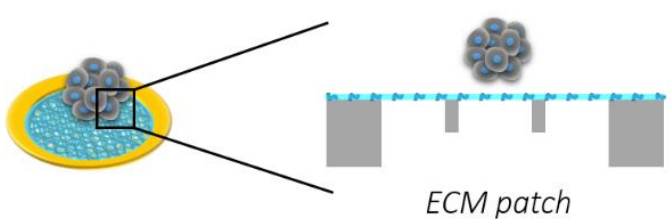

ECM patch

Figure 1. Schematic diagram of micro device fabrication for tumor cell growth and processing. (A) Fabrication of the gelatin/agarose patch for spheroid growth. (B) Tumor spheroid formation in honeycomb compartment with an agarose membrane. (C) Fabrication of the ECM patch and (D) spheroid plating on ECM patch.

One important challenge in the field is to control the size and homogeneity of the spheroids. To this aim, we have changed the dimensions of the honeycomb microframe: the width (W) of the honeycomb (200 and $400 \mu \mathrm{m})$ and the height $(\mathrm{H})$ of the walls $(50$ and $200 \mu \mathrm{m})$ (Figure 2A). Two patches were fabricated: W200H50 and W400H200 (Figure S1). 
bioRxiv preprint doi: https://doi.org/10.1101/2021.11.24.469887; this version posted November 25, 2021. The copyright holder for this preprint (which was not certified by peer review) is the author/funder, who has granted bioRxiv a license to display the preprint in perpetuity. It is made

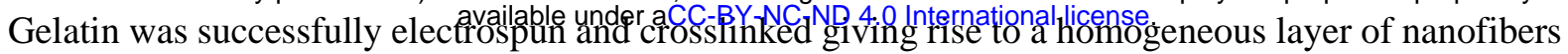
whatever the dimensions of the microframe (Figure S2). A solution of agarose was subsequently drop cast, giving rise to a homogeneous non-adherent film that was successfully maintained in $200 \mu \mathrm{m}$ high honeycombs (Figure 2B).

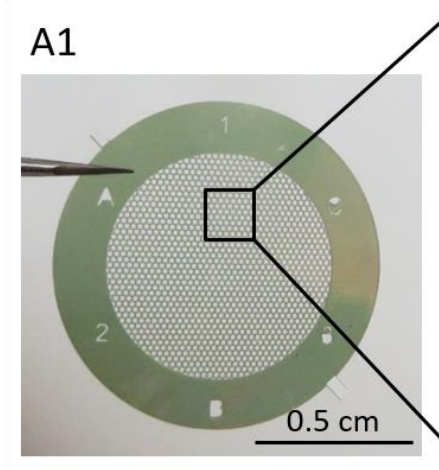

B1 - top view

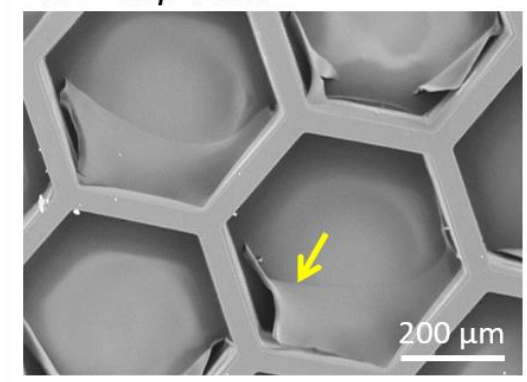

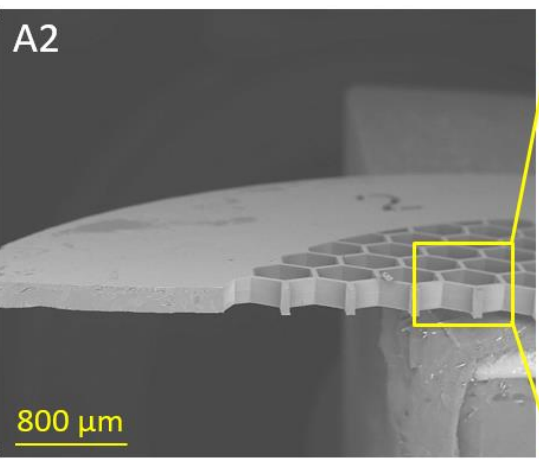

B2 - bottom view

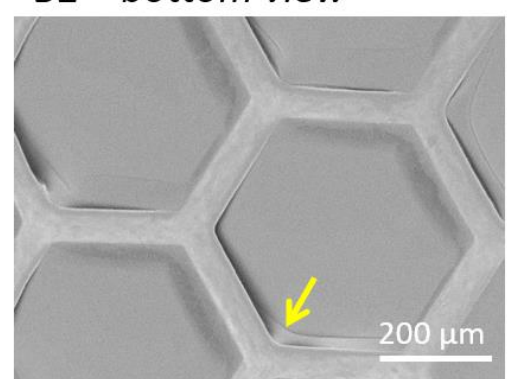

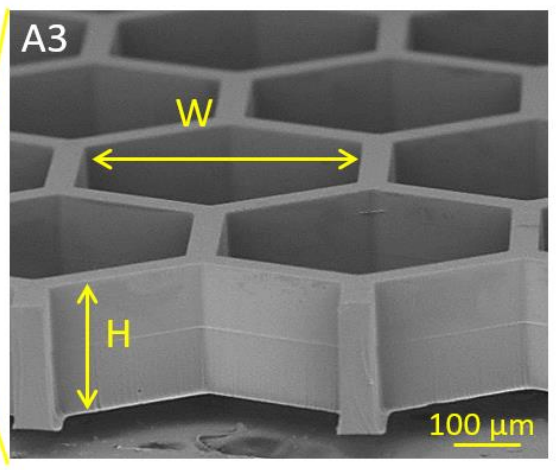

B3 - cross section

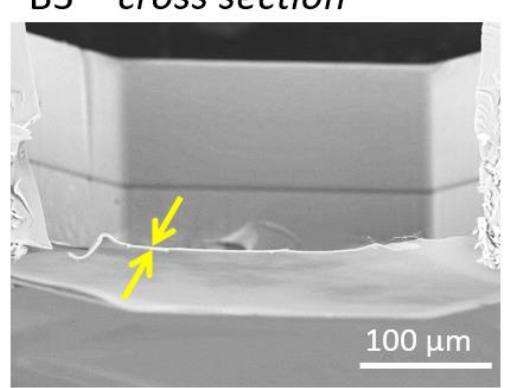

Figure 2. (A) Bare patch: (A1) Photograph and (A2,3) SEM images of the fabricated W400H200 patch. (B) SEM images of the coating of patches with gelatin nanofibers topped with agarose film (see yellow arrows) for spheroid growth: (B1) top view, (B2) bottom view and (B3) cross-section.

\subsection{Growth of human ovarian spheroids}

After coating the patch, SKOV-3 cells have been seeded on the W200H50 and W400H200 patches. Different cell seeding densities have been tested. We have selected 100000 cells per patch and 400000 cells per patch for $\mathrm{W} 200 \mathrm{H} 50$ and $\mathrm{W} 400 \mathrm{H} 200$ respectively that were found to be the maximal cell density allowing to grow a single spheroid per honeycomb compartment and preventing overflow of cells into layers (Figure S3). Figure 3A shows the formation of the spheroids during the first three days after seeding SKOV-3 on W200H50 patches. Starting from isolated cells, at day 0, we can clearly see the aggregation of cells into circular structures that occurs after one day and slowly evolves going from $91 \mu \mathrm{m}$ to $109 \mu \mathrm{m}$ in diameter after three days (Figure 3B and Table S1). The spheroids obtained after three days exhibit an aspect ratio of 1 (Figure S4) with a Gaussian distribution of their size (Figure 3C). The same trend is observed after seeding cells on W400H200 patches, going from isolated to rapidly aggregating assemblies obtained after one day (Figure 3D). These assemblies grow slowly, going from 214 to $235 \mu \mathrm{m}$ after three days (Figure 3E and Table S2). After three days, homogeneous spheroids with an aspect ratio of 1 were obtained (Figure 3F and Figure S5). Interestingly, the spheroids are more 
bioRxiv preprint doi: https://doi.org/10.1101/2021.11.24.469887; this version posted November 25, 2021. The copyright holder for this preprint (which was not certified by peer review) is the author/funder, who has granted bioRxiv a license to display the preprint in perpetuity. It is made

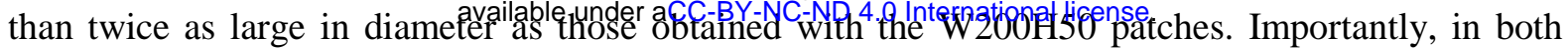
systems, nearly all honeycombs contained a spheroid. Given that W200H50 and W400H200 are made up of $c a .1350$ and 400 honeycombs respectively, we expect a minimum of $c a .70$ and 1000 cells per spheroid with respect to the initial cell density.

The 3D spherical aspect of the spheroids was further checked using immunofluorescence microscopy (Figure 3G). Staining was directed towards E-Cadherin cell junctions, which is an epithelial marker, together with the staining of the nuclei (DAPI staining). These observations show that the fluorescence intensity of both markers is higher at the edge of the spheroid compared to the core due to the limited diffusion of the fluorescent probe within the dense cellular aggregate. However, E-cadherin cell junctions are clearly observed (Figure 3G insert). In parallel, spheroids were stained for vimentin, a cytoskeletal protein upregulated during cell transitioning events and whose expression is associated with mesenchymal phenotypes, showing a hardly detectable signal (Figure S6). These observations highlight the specificity of the epithelial marker staining and indicate the epithelial phenotype of the SKOV-3 cells within the spheroids. Very importantly, the 3D reconstruction confirmed the spherical, slightly flattened, aspect of the spheroid. 
bioRxiv preprint doi: https://doi.org/10.1101/2021.11.24.469887; this version posted November 25, 2021. The copyright holder for this preprint (which was not certified by peer review) is the author/funder, who has granted bioRxiv a license to display the preprint in perpetuity. It is made available under aCC-BY-NC-ND 4.0 International license.

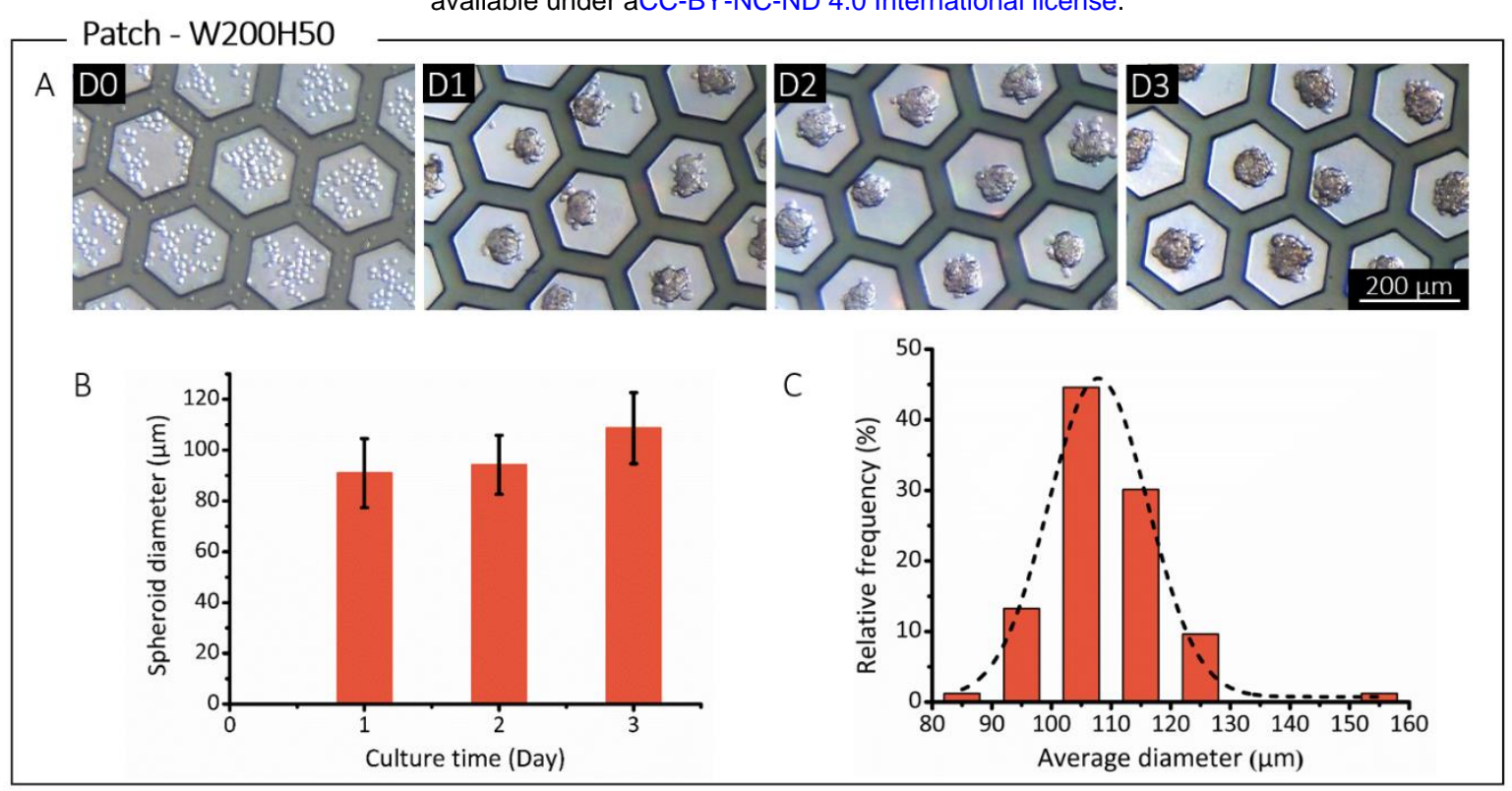

Patch - W4OOH2OO
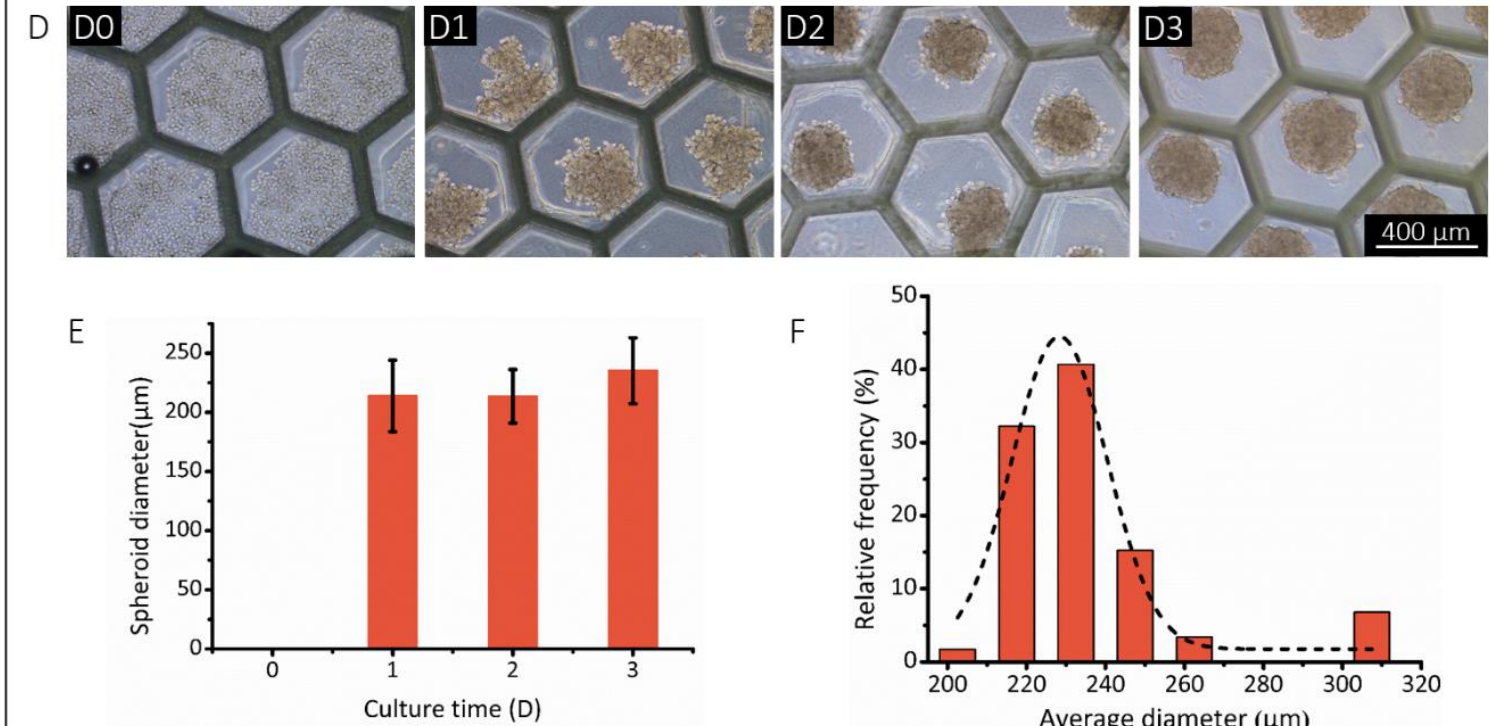

G
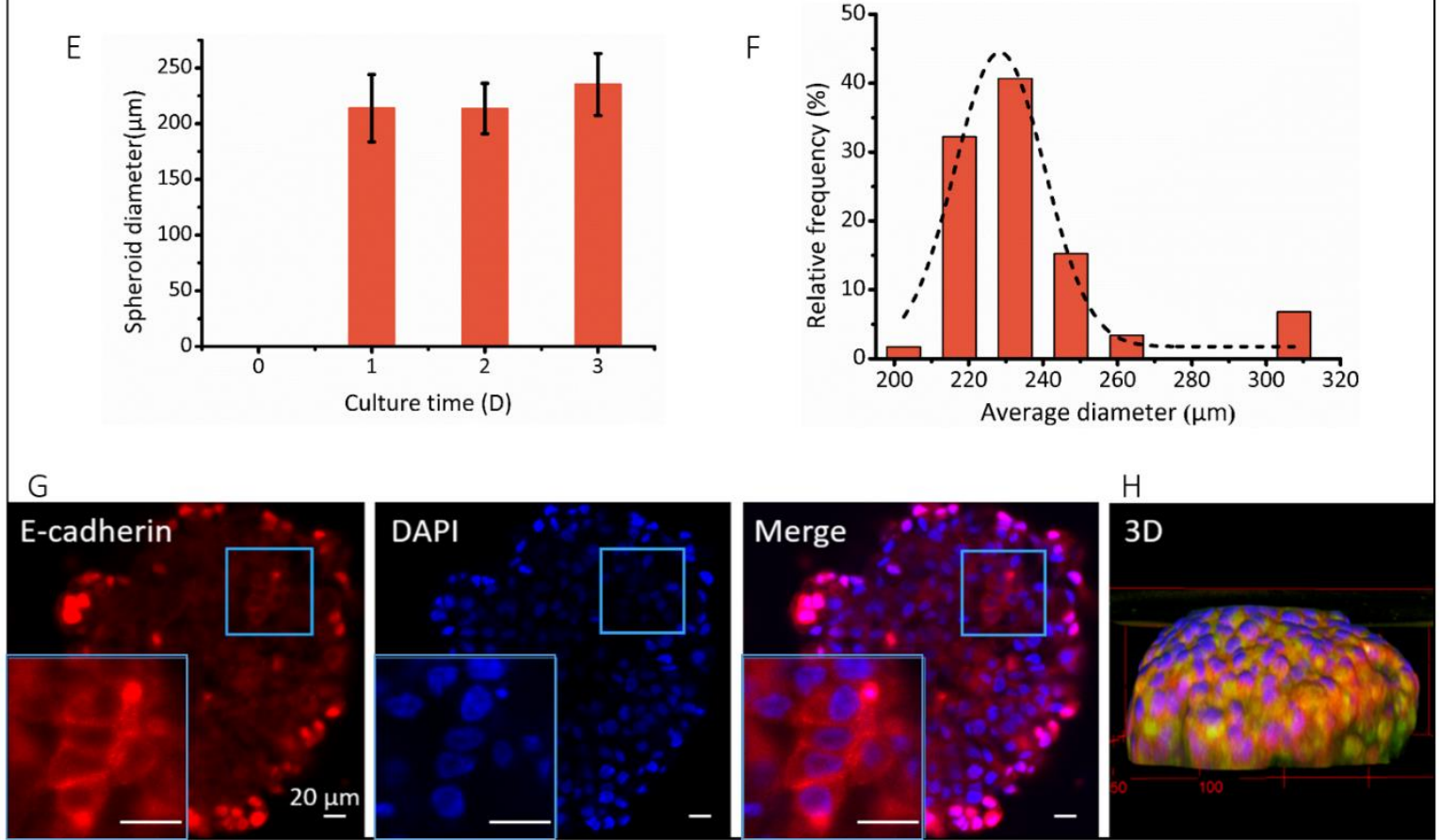

Figure 3. Spheroid growth on (A-C) W200H50 and (D-G) W400H200 patches. (A,D) Optical microscopy images of spheroid growth, 1, 2, and 3 days after SKOV-3 seeding. (B,E) Histograms of the spheroid diameters as a function of culture time, and (C,F) distribution of spheroid size 3 days after SKOV-3 seeding. (G) Immunofluorescence image of a SKOV-3 spheroid (Z-slice) and (H) 3D reconstruction of a second spheroid (epithelial markers EpCAM (in green) and E-cadherin (in red) and nuclei (DAPI in blue). 
bioRxiv preprint doi: https://doi.org/10.1101/2021.11.24.469887; this version posted November 25, 2021. The copyright holder for this preprint (which was not certified by peer review) is the author/funder, who has granted bioRxiv a license to display the preprint in perpetuity. It is made

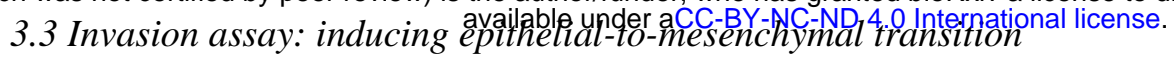

Tumor spheroids obtained were stable and could be handled and removed easily to be re-seeded on a second type of patches mimicking the ECM. These biologically relevant ECM patches are obtained by drop casting of type I collagen as model of connective tissues (Figure 1C,D). Figure 4A shows the characterization of the ECM patch using multiphoton microscopy based on second harmonic generation (SHG) [30]. This imaging modality allows to monitor unlabeled collagen I with high specificity towards its fibrillary hierarchical organization. These images show the fibrillary structure of the network, which is few micron in thickness. After seeding of the spheroids, migration could be observed with highly different phenotypes from the core to the front of the spheroidal aggregate (Figure 4B). Staining of the nucleus (DAPI staining) and actin (phalloidin staining) were combined with the immunostaining of vimentin, which is commonly used as a marker of epithelial-to-mesenchymal plasticity. Fluorescence microscopy images revealed the cellular heterogeneity associated to the invasive migration of metastatic cell aggregates. In the core, epithelial phenotypes could be observed, as previously identified within the spheroids (Figure 4C1). At the front of the aggregate, cells with different phenotypes could be observed, characterized by elongated nucleus and a high cortical expression of vimentin, which colocalized with the actin cytoskeleton (Figure 4C2). This is characteristic of mesenchymal phenotypes and shows that cells transitioning within the epithelial-to-mesenchymal spectrum in the course of the invasion process is reproduced on the patch. 
bioRxiv preprint doi: https://doi.org/10.1101/2021.11.24.469887; this version posted November 25, 2021. The copyright holder for this preprint (which was not certified by peer review) is the author/funder, who has granted bioRxiv a license to display the preprint in perpetuity. It is made available under aCC-BY-NC-ND 4.0 International license.
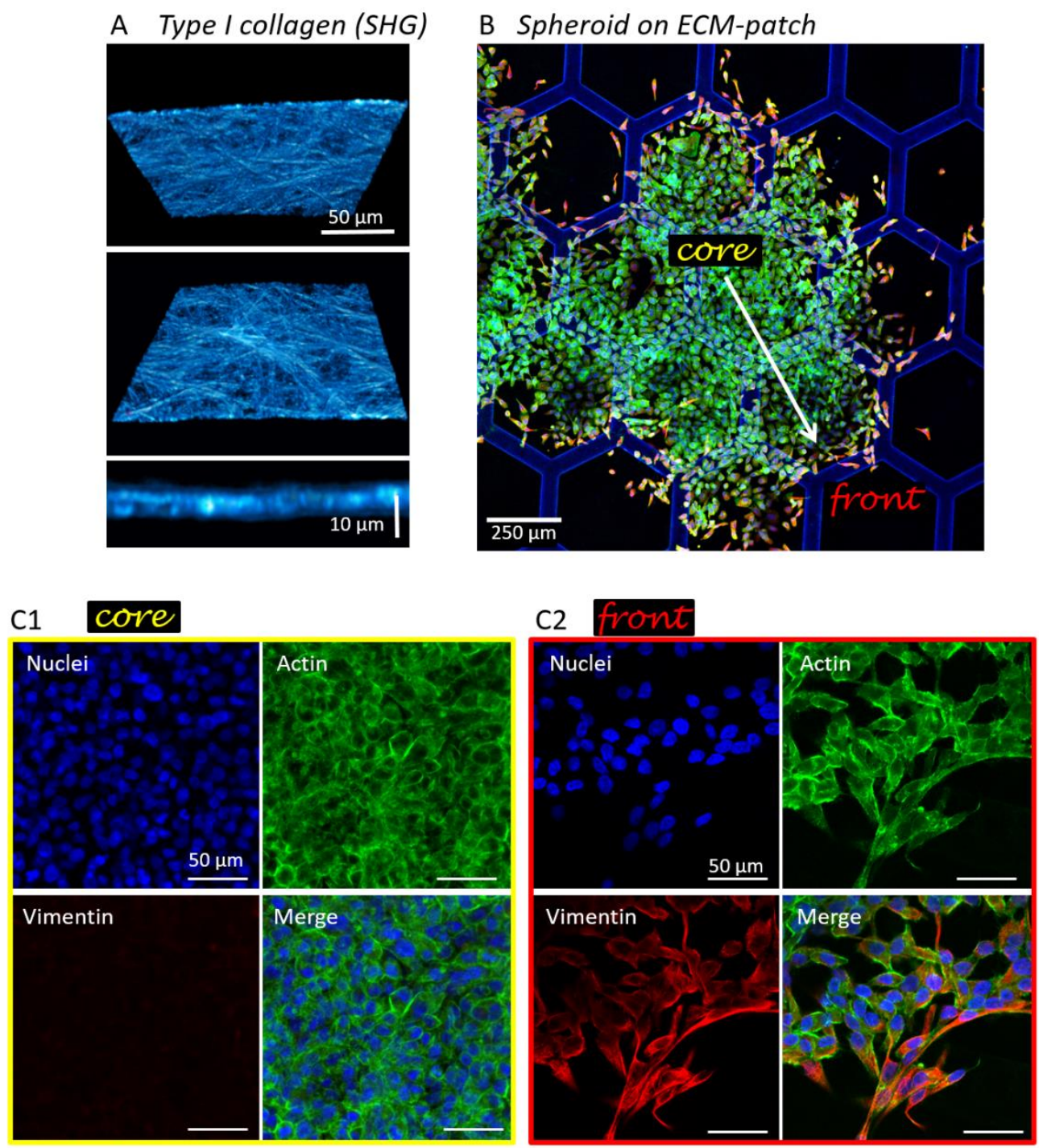

Figure 4. (A) Top, bottom and side view of the ECM patch using SHG. (B-C) Immunofluorescence image of SKOV-3 spheroids from W200H50 patches two days after seeding on ECM-coated patch. Cells were stained for vimentin (red), actin (green), and nuclei (blue).

Finally, one important advantage of using this strategy is the possibility to integrate the patch into a diversity of microfluidic chips for the development of various bioassays [24,34-37]. This will be particularly relevant for modeling ovarian cancers that are very sensitive to their surrounding microenvironment [38], which includes the soluble environment, the ascites that is an excess fluid resulting from lymphatic obstruction found in physio-pathological conditions [39] and that has been shown to play a role in EMT [40].

\section{Conclusions}

We have developed a robust strategy to control the size and the number of cells in spheroids obtained from human OC cells. Playing with the dimensions of porous microfabricated supports allowed to grow spheroids from SKOV-3 cells with diameter in the 90 to $235 \mu \mathrm{m}$ range. We have shown that spheroid 
bioRxiv preprint doi: https://doi.org/10.1101/2021.11.24.469887; this version posted November 25, 2021. The copyright holder for this preprint (which was not certified by peer review) is the author/funder, who has granted bioRxiv a license to display the preprint in perpetuity. It is made

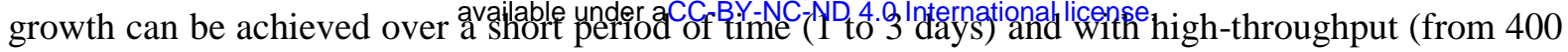
to more than 1300 spheroids depending on the patch). These stable spheroids can be handled and transferred on different kinds of supports. This provides a new in vitro model, which recapitulates the tumor environment with varying metastatic assemblies and adjustable microenvironment structure. Because these patches can be easily incorporated within microfluidic chips, it provides a mean to control and explore independently the impact of the shear stress and soluble factors (flow and circulating environment) on metastatic behaviors of OC cells. Hence, this strategy is an asset to adapt genetic tools to tune collective and single cell behavior as a function of the microenvironment, in a flexible and easy way. The invasion assay will provide the biological and biomedical community with unique tools for investigating collective migratory behaviors and epithelial-to-mesenchymal transition at play in physiological and pathological context typically embryogenesis and cancer. The possibility to independently control the metastasis size, microenvironment structure and screen anti-cancer drugs represents a new perspective for cancer-on-a-chip research.

\section{Acknowledgements}

This project has received financial support from the CNRS through the. Changchong Chen thanks the China Scholarship Council for his PhD grant.

\section{References}

[1] M.E. Katt, A.L. Placone, A.D. Wong, Z.S. Xu, P.C. Searson, In vitro tumor models: advantages, disadvantages, variables, and selecting the right platform, Bioeng. Biotechnol. 4 (2016) 12.

[2] E.C. Costa, A.F. Moreira, D. de Melo-Diogo, V.M. Gaspar, M.P. Carvalho, I.J. Correia, 3D tumor spheroids: an overview on the tools and techniques used for their analysis, Biotechnol. Adv. 34 (8) (2016) 1427-1441.

[3] T. Rodrigues, B. Kundu, J. Silva-Correia, S.C. Kundu, J.M. Oliveira, R.L. Reis, V.M. Correlo, Emerging tumor spheroids technologies for 3D in vitro cancer modeling, Pharmacol. Ther. 184 (2018) 201-211.

[4] S. Kellouche, J. Fernandes, J. Leroy-Dudal, O. Gallet, S. Dutoit, L. Poulain, F. Carreiras. Initial formation of IGROV1 ovarian cancer multicellular aggregates involves vitronectin, Tumor Biol. 31 (2010) 129-139.

[5] L. Carduner, C.R. Picot, J. Leroy-Dudal, L. Blay, S. Kellouche, F. Carreiras, Cell cycle arrest or survival signaling through $\alpha \mathrm{v}$ integrins, activation of PKC and ERK1/2 lead to anoikis resistance of ovarian cancer spheroids, Exp. Cell Res. 320 (2014) 329-342.

[6] S. Raghavan, P. Mehta, M.R. Ward, M.E. Bregenzer, E.M.A. Fleck, L. Tan, K. McLean, R.J. Buckanovich, G. Mehta, Personalized medicine-based approach to model patterns of chemoresistance 
bioRxiv preprint doi: https://doi.org/10.1101/2021.11.24.469887; this version posted November 25, 2021. The copyright holder for this preprint (which was not certified by peer review) is the author/funder, who has granted bioRxiv a license to display the preprint in perpetuity. It is made

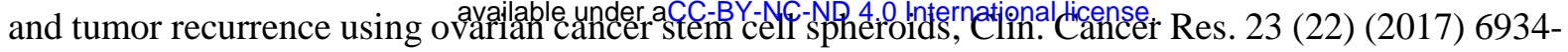
6945.

[7] N. Casagrande, C. Borghese, F. Agostini, C. Durante, M. Mazzucato, A. Colombatti, D. Aldinucci, In ovarian cancer multicellular spheroids, platelet releasate promotes growth, expansion of aldh+ and cd133+ cancer stem cells, and protection against the cytotoxic effects of cisplatin, carboplatin and paclitaxel, Int. J. Mol. Sci., 22 (6) (2021) 3019.

[8] O.M. Kutova, L.M. Sencha, A.D. Pospelov, O.E. Dobrynina, A.A. Brilkina, E.I. Cherkasova, I.V. Balalaeva, Comparative analysis of cell-cell contact abundance in ovarian carcinoma cells cultured in two - and three - dimensional in vitro models, Biology, 9 (12) (2020) 446.

[9] Y.-C. Tung, A.Y. Hsiao, S.G. Allen, Y.-s. Torisawa, M. Ho, S. Takayama, High-throughput 3D spheroid culture and drug testing using a 384 hanging drop array, Analyst, 136 (3) (2011) 473-478.

[10] R. Foty, A simple hanging drop cell culture protocol for generation of 3D spheroids, J. Vis. Exp. 6 (51) (2011) 2720.

[11] F. Castaneda, R.K. Kinne, Short exposure to millimolar concentrations of ethanol induces apoptotic cell death in multicellular HepG2 spheroids, J. Cancer Res. Clin. Oncol, 126 (6) (2000) 305310.

[12] Z. Guo, T. Zhang, K. Fang, J. Dou, N. Zhou, X. Maab, N. Gu, The effects of macroporosity and stiffness of poly[(methyl vinyl ether)-: Alt -(maleic acid)] cross-linked egg white simulations of an aged extracellular matrix on the proliferation of ovarian cancer cells, RSC Adv. 6 (2016) 43892-43900.

[13] D. Loessner, K.S. Stok, M.P. Lutolf, D.W. Hutmacher, J.A. Clements, S.C. Rizzi, Bioengineered 3D platform to explore cell-ECM interactions and drug resistance of epithelial ovarian cancer cells, Biomaterials, 31 (32) (2010) 8494-8506.

[14] N. Zhou, X. Ma, W. Hu, P. Ren, Y. Zhao, T. Zhang, Effect of RGD content in poly(ethylene glycol)-crosslinked poly(methyl vinyl ether-alt-maleic acid) hydrogels on the expansion of ovarian cancer stem-like cells, Mater. Sci. Eng. C Mater. Biol. Appl. 118 (2021) 111477.

[15] N. Zhou, X. Ma, T. Zhang, X. Chen, Z. Guo, D. Ma, N. Gu, Enrichment of ovarian cancer stem cells by PEG cross-linked PMVE-co-MA hydrogel with controllable elastic modulus, J. Nanosci. Nanotechnol. 16 (12) (2016) 12134-12144.

[16] D. Loessner, C. Meinert, E. Kaemmerer, L.C. Martine, K. Yue, P.A. Levett, T.J. Klein, F.P.W. Melchels, A. Khademhosseini, D.W. Hutmacher, Functionalization, preparation and use of cell-laden gelatin methacryloyl-based hydrogels as modular tissue culture platforms, Nat. Protoc. 11 (4) (2016) 727-746.

[17] H. Song, G.-H. Cai, J. Liang, D.-S. Ao, H. Wang, Z.-H. Yang, Three-dimensional culture and clinical drug responses of a highly metastatic human ovarian cancer HO-8910PM cells in nanofibrous microenvironments of three hydrogel biomaterials, J. Nanobiotechnology, 18 (1) (2020) 90. 
bioRxiv preprint doi: https://doi.org/10.1101/2021.11.24.469887; this version posted November 25, 2021. The copyright holder for this preprint (which was not certified by peer review) is the author/funder, who has granted bioRxiv a license to display the preprint in perpetuity. It is made

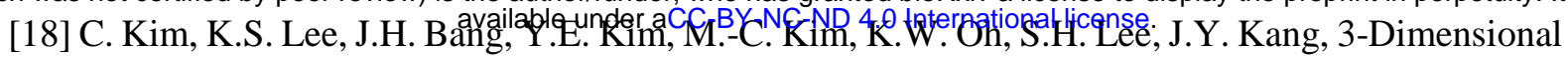
cell culture for on-chip differentiation of stem cells in embryoid body, Lab Chip, 11 (5) (2011) 874 882.

[19] C. Kim, J.H. Bang, Y.E. Kim, S.H. Lee, J.Y. Kang, On-chip anticancer drug test of regular tumor spheroids formed in microwells by a distributive microchannel network, Lab Chip, 12 (20) (2012) 41354142.

[20] T. Masiello, A. Dhall, L.P.M. Hemachandra, N. Tokranova, J.A. Melendez, J. Castracane, A Dynamic Culture Method to Produce Ovarian Cancer Spheroids under Physiologically-Relevant Shear Stress, Cells 7 (12) (2018) 277.

[21] Y.C. Chen, X. Lou, Z. Zhang, P. Ingram, E. Yoon, High-Throughput Cancer Cell Sphere Formation for Characterizing the Efficacy of Photo Dynamic Therapy in 3D Cell Cultures, Sci. Rep. 5 (2015) 12175.

[22] J.S. Suarez, H.G. Main, G.G. Muralidhar, O. Elfituri, H.-L. Xu, A.A. Kajdacsy-Balla, M.V. Barbolina, CD44 regulates formation of spheroids and controls organ-specific metastatic colonization in epithelial ovarian carcinoma, Mol. Cancer Res. 17 (9) (2019) 1801-1814.

[23] Y. He, B. Huang, E. Rofaani, J. Hu, Y. Liu, G. Pitingolo, L. Wang, J. Shi, C. Aimé, Y. Chen, Fabrication of micro-cages and caged tumor spheroids for microfluidic chip-based assays, Microelectron. Eng. 225 (2020) 111256.

[24] S. Klaschik, J. Gehlen, C. Neumann, M.-D. Keyver-Paik, M. Soehle, S. Frede, M. Velten, A. Hoeft, T. Hilbert, Network of Mediators for Vascular Inflammation and Leakage Is Dysbalanced during Cytoreductive Surgery for Late-Stage Ovarian Cancer, Mediators Inflamm. (2019) 5263717.

[25] N. Dadgar, A.M. Gonzalez-Suarez, P. Fattahi, X. Hou, J.S. Weroha, A. Gaspar-Maia, G. Stybayeva, A. Revzin, A microfluidic platform for cultivating ovarian cancer spheroids and testing their responses to chemotherapies, Microsyst. Nanoeng. 6 (2020) 93.

[26] W. Cui, Y. Zhou, J. Chang, Electrospun nanofibrous materials for tissue engineering and drug delivery, Sci. Technol. Adv. Mater. 11 (1) (2010) 014108.

[27] F. Gobeaux, G. Mosser, A. Anglo, P. Panine, P. Davidson, M.-M. Giraud-Guille, E. Belamie, Fibrillogenesis in dense collagen solutions: a physicochemical study, J. Mol. Biol. 376 (5) (2008) 15091522.

[28] M.-M. Giraud-Guille, L. Besseau, D. Herbage, P. Gounon, Optimization of Collagen Liquid Crystalline Assemblies: Influence of Sonic Fragmentation, J. Struct. Biol. 113 (2) (1994) 99-106.

[29] I. Bergman, R. Loxley, Two Improved and Simplified Methods for the Spectrophotometric Determination of Hydroxyproline, Anal. Chem. 35 (12) (1963) 1961-1965.

[30] C. Teulon, A. Tidu, F. Portier, G. Mosser, M.-C. Schanne-Klein, Probing the 3D structure of cornea-like collagen liquid crystals with polarization-resolved SHG microscopy, Opt. Express, 24 (14) (2016) 16084-16098. 
bioRxiv preprint doi: https://doi.org/10.1101/2021.11.24.469887; this version posted November 25, 2021. The copyright holder for this preprint (which was not certified by peer review) is the author/funder, who has granted bioRxiv a license to display the preprint in perpetuity. It is made

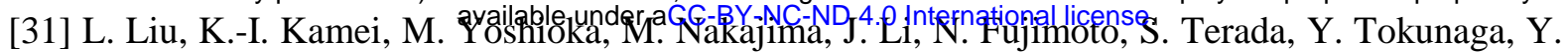

Koyama, H. Sato, K. Hasegawa, N. Nakatsuji, Y. Chen, Nano-on-micro fibrous extracellular matrices for scalable expansion of human ES/iPS cells, Biomaterials 124 (2017) 47-54.

[32] Y. Tang, L. Liu, J. Li, L. Yu, F.P.U. Severino, L. Wang, J. Shi, X. Tu, V. Torre, Y. Chen, Effective motor neuron differentiation of hiPSCs on a patch made of crosslinked monolayer gelatin nanofibers, J. Mater. Chem. B, 4 (19) (2016) 3305-3312.

[33] Y. Tang, L. Liu, J. Li, L. Yu, L. Wang, J. Shi, Y. Chen, Induction and differentiation of human induced pluripotent stem cells into functional cardiomyocytes on a compartmented monolayer of gelatin nanofibers, Nanoscale, 8 (30) (2016) 14530-14540.

[34] X. Li, L. Liu, L. Wang, K.-i Kamei, Q. Yuan, F. Zhang, J. Shi, A. Kusumi, M. Xie, Z. Zhao, Y. Chen, Integrated and diffusion-based micro-injectors for open access cell assays, Lab Chip 11 (15) (2011) 2612-2617.

[35] L. Wang, Z.L. Zhang, J. Wdzieczak-Bakala, D.-W. Pang, J. Liu, Y. Chen, Patterning cells and shear flow conditions: convenient observation of endothelial cell remoulding, enhanced production of angiogenesis factors and drug response, Lab Chip 11 (24) (2011) 4235-4240.

[36] Y. Tang, J. Shi, S. Li, L. Wang, Y.E. Cayre, Y. Chen, Microfluidic device with integrated microfilter of conical-shaped holes for high efficiency and high purity capture of circulating tumor cells, Sci. Rep. 4 (2014) 6052.

[37] K.-i. Kamei, Y. Koyama, Y. Tokunaga, Y. Mashimo, M. Yoshioka, C. Fockenberg, R. Mosbergen, O. Korn, C. Wells, Y. Chen, Characterization of Phenotypic and Transcriptional Differences in Human Pluripotent Stem Cells under 2D and 3D Culture Conditions, Adv. Healthc. Mater. 5 (22) (2016) 29512958.

[38] I. Rivzi, U.A. Gurkan, S. Tasoglu, N. Alagic, J.P. Celli, L.B. Mensah, Z. Mai, U. Demirci, T. Hasan, Flow induces epithelial-mesenchymal transition, cellular heterogeneity and biomarker modulation in 3D ovarian cancer nodules, Proc. Natl. Acad. Sci. USA, 110 (22) (2013) E1974-E1983. [39] G.B. Feldman, R.C. Knapp, S.E. Order, S. Hellman, The role of lymphatic obstruction in the formation of ascites in a murine ovarian carcinoma, Cancer Res. 32 (8) (1972) 1663-1666.

[40] L. Carduner, J. Leroy-Dudal, C.R. Picot, O. Gallet, F. Carreiras, S. Kellouche, Ascites-induced shift along epithelial-mesenchymal spectrum in ovarian cancer cells: enhancement of their invasive behavior partly dependant on $\alpha$ v integrins, Clin. Exp. Metastasis, 31 (6) (2014) 675-688. 